\title{
BILANGAN KROMATIK LOKASI GRAF TAK TERHUBUNG DENGAN GRAF LINGKARAN SEBAGAI KOMPONEN-KOMPONENNYA
}

\author{
FADHILA RADIAH ANAS, DES WELYYANTI, EFFENDI \\ Program Studi S1 Matematika, \\ Fakultas Matematika dan Ilmu Pengetahuan Alam, Universitas Andalas, \\ Kampus UNAND Limau Manis Padang, Indonesia. \\ email : fadhilaradiahanas@gmail.com
}

\begin{abstract}
Abstrak. Misalkan $G=(V, E)$ suatu graf terhubung dan c suatu k-pewarnaan dari $G$. Kelas warna pada $G$ adalah himpunan titik-titik yang berwarna $i$, dinotasikan dengan $S_{i}$ untuk $1 \leq i \leq k$. Misalkan $\Pi=\left\{S_{1}, S_{2}, \cdots, S_{k}\right\}$ adalah partisi terurut dari $V(G)$ berdasarkan pewarnaan titik, maka representasi $v$ terhadap $\Pi$ disebut kode warna dari $v$, dinotasikan dengan $c_{\Pi}(v)$. Kode warna $c_{\Pi}(v)$ dari suatu titik $v \in V(G)$ didefinisikan sebagai vektor- $k$ :

$$
c_{\Pi}(v)=\left(d\left(v, S_{1}\right), d\left(v, S_{2}\right), \cdots, d\left(v, S_{k}\right)\right)
$$

dimana $\left.d\left(v, S_{i}\right)=\min \left\{d(v, x) \mid x \in S_{i}\right)\right\}$, untuk $1 \leq i \leq k$. Jika setiap titik yang berbeda di $G$ memiliki kode warna yang berbeda untuk suatu $\Pi$, maka c disebut pewarnaan lokasi untuk $G$. Jumlah warna minimum yang digunakan pada pewarnaan lokasi dari graf $G$ disebut bilangan kromatik lokasi untuk $G$, dinotasikan dengan $\chi_{L}(G)$. Pada penelitian ini akan dibahas tentang penentuan bilangan kromatik lokasi pada graf prisma berekor.

Kata Kunci: Bilangan Kromatik Lokasi, Graf Tak Terhubung, Graf Lingkaran, Komponen
\end{abstract}

\section{Pendahuluan}

Salah satu kajian yang terdapat dalam teori graf adalah mengenai pewarnaan lokasi graf dan kajian ini merupakan suatu kajian yang cukup baru dalam teori graf. Untuk pertama kalinya kajian tentang konsep pewarnaan lokasi graf dikaji oleh Chartrand dkk (2002) [1], dengan menentukan suatu bilangan kromatik lokasi dari beberapa graf seperti, graf lintasan $P_{n}$ dengan $\mathrm{n} \geqslant 3$ diperoleh bilangan kromatik lokasi, $\chi_{L}\left(P_{n}\right)=3$. Untuk graf lingkaran diperoleh $\chi_{L}\left(C_{n}\right)=3$ untuk $n$ ganjil atau $\chi_{L}\left(C_{n}\right)=4$ untuk $n$ genap. Konsep pewarnaan lokasi graf muncul akibat pengembangan dari dua konsep dalam graf yaitu pewarnaan titik pada graf dan dimensi partisi graf. Pewarnaan titik pada graf adalah pemberian warna untuk setiap titik pada graf dengan syarat setiap titik yang bertetangga harus memiliki warna yang berbeda. Banyaknya warna minimum yang digunakan untuk pewarnaan titik pada graf $G$ disebut bilangan kromatik lokasi yang dinotasikan dengan $\chi_{L}(G)$. 
Selanjutnya, beberapa penelitian Welyyanti dkk (2014) [3] memperluas mengenai definisi bilangan lokasi kromatik suatu graf dapat diaplikasikan pada semua jenis graf termasuk graf tak terhubung. Graf $G$ adalah pasangan himpunan $V$ dan $E$, dituliskan $G=(V, E)$, dimana $V$ adalah suatu himpunan titik (vertex) yang tidak kosong dan $E$ adalah himpunan sisi (edge) yang terdiri dari pasangan terurut dari titik-titik berbeda dari $V$. Misalkan $V=\left\{v_{1}, v_{2}, \cdots, v_{n}\right\}$ adalah himpunan titik yang berisi $n$ titik di $G$ dan $E=\left\{e_{1}, e_{2}, \cdots, e_{m}\right\}$ adalah himpunan sisi yang berisi $m$ sisi di $G$. secara umum, untuk menotasikan sisi dapat ditulis dengan $v_{i} v_{j}$ atau $v_{j} v_{i}$. Graf lingkaran (cycle) adalah graf yang setiap titiknya berderajat dua. Dinotasikan dengan $C_{n}, n \geq 3$.

\section{Beberapa Definisi}

Bilangan kromatik lokasi dari graf tak terhubung adalah sebagai berikut: misalkan $H$ adalah graf tak terhubung dan $c$ adalah pewarnaan- $t$ titik pada $H$ yang menginduksi partisi $\Pi=\left\{S_{1}, S_{2}, \ldots, S_{t}\right\}$ dari $V(H)$. Kode warna dari titik $v \in V(H)$ adalah $c_{\Pi}(v)\left(d\left(v, S_{1}\right), d\left(v, S_{2}\right), \ldots, d\left(v, S_{t}\right)\right)$ dengan $d\left(v, S_{i}\right)=\min \left\{d(v, x) \mid x \in S_{i}\right\}$ dan $d\left(v \mid S_{i}\right)<\infty$ untuk $1 \leqslant i \leqslant$ t. Pewarnaan $c$ dikatakan pewarnaan lokasi- $t$ jika semua kode warna dari semua titik di $H$ berbeda. Bilangan kromatik lokasi dari graf tak terhubung $(H)$, dinotasikan dengan $\chi_{L}^{\prime}(\mathrm{H})$, adalah bilangan bulat terkecil $t$ sedemikian sehingga $H$ mempunyai $t$-pewarnaan lokasi. Jika tidak ada nilai $t$ yang memenuhi maka $\chi_{L}^{\prime}(\mathrm{H})=\infty$. Jadi, bilangan kromatik lokasi untuk graf tak terhubung dapat bernilai hingga dan tak hingga.

Chartrand dkk.(2002) telah memberikan teorema dan akibat dasar bilangan kromatik lokasi suatu graf. Teorema tersebut dijelaskan pada teorema-teorema di bawah ini. Definisikan $N(v)$ sebagai himpunan yang berisi semua titik yang menjadi tetangga dari $v$.

Teorema 2.1. [2] Misalkan c adalah suatu pewarnaan lokasi pada graf terhubung $G$. Jika $u$ dan $v$ adalah dua titik pada graf $G$ sedemikian sehingga $d(u, w)=d(v, w)$ untuk setiap $w \in V(G) \backslash\{u, v\}$, maka $c(u) \neq c(v)$. Dalam hal khusus, jika $u$ dan $v$ adalah titik-titik yang tidak bertetangga di $G$ sedemikian sehingga $N(u)=N(v)$, $\operatorname{maka} c(u) \neq c(v)$.

Akibat 2.2. [2] Jika $G$ adalah suatu graf terhubung yang memuat suatu titik yang bertetangga dengan $k$ daun di $G$, maka $\chi_{L}(G) \geq k+1$.

Teorema 2.3. [3] Untuk setiap i, misal $G_{i}$ adalah suatu graf terhubung dan misalkan $H=\bigcup_{i=1}^{m} G_{i}$. Jika $\chi_{L}^{\prime}(H)<\infty$, maka $q \leq \chi_{L}^{\prime}(H) \leq r$, dimana $q=$ $\max \left\{\chi_{L}\left(G_{i}\right): i \in[1, m]\right\}$ dan $r=\min \left\{\left|V\left(G_{i}\right)\right|: i \in[1, m]\right\}$.

\section{Bilangan Kromatik Lokasi Graf Tak Terhubung Dengan Graf Lingkaran Sebagai Komponen-Komponennya}

Pada bab ini akan dibahas tentang penentuan bilangan kromatik lokasi untuk graf tak terhubung dengan graf lingkaran $C_{4}$ sebagai komponen- komponennya yang dinotasikan sebagai $H=k C_{4}$, untuk $k \geq 2$. 
Teorema 3.1. Misalkan graf $C_{4}$ adalah sebuah graf lingkaran dengan 4 titik. jika $H=k C_{4}, m a k a$

$$
\chi_{L}^{\prime}(H)=\left\{\begin{array}{l}
4, \text { untuk } k=2,3 \\
\infty, \text { untuk lainnya }
\end{array} .\right.
$$

Bukti. Misalkan $c$ adalah pewarnaan titik di $H$ dan $\Pi=\left\{S_{1}, S_{2}, \ldots, S_{t}\right\}$ adalah suatu partisi titik-titik pada graf $H$ dengan $S_{i}$ menyatakan kelas warna ke- $i$ untuk $1 \leqslant \mathrm{i} \leqslant \mathrm{t}$. Akan ditentukan bilangan kromatik lokasi graf $H$. Dalam menentukan bilangan kromatik lokasi, terdapat beberapa syarat yang harus dipenuhi. Pertama, setiap titik yang bertetangga tidak boleh diwarnai dengan warna yang sama. Selanjutnya, kode warna setiap titik di $H$ terhadap $\Pi$ haruslah berbeda atau dinotasikan $c_{\Pi}\left(v_{i}\right) \neq c_{\Pi}\left(v_{t}\right)$ untuk $i \neq t$.

Kasus 1. Akan ditunjukkan $\chi_{L}^{\prime}(H)=4$ untuk $\mathrm{k}=2$, 3. Akan ditunjukkan $\chi_{L}^{\prime}(H) \leq$ 4 untuk $\mathrm{k}=2,3.2 C_{4}$ merupakan subgraf dari $3 C_{4}$ maka cukup dibuktikan bahwa setiap titik di $3 C_{4}$ mempunyai kode warna yang berbeda.

Misalkan

$$
\begin{aligned}
V(H) & =V\left(C_{4}^{(1)}\right) \bigcup V\left(C_{4}^{(2)}\right) \bigcup V\left(C_{4}^{(3)}\right), \text { dengan } \\
V\left(C_{4}^{(1)}\right) & =\left\{v_{1}, v_{2}, v_{3}, v_{4}\right\} \\
V\left(C_{4}^{(2)}\right) & =\left\{w_{1}, w_{2}, w_{3}, w_{4}\right\} \\
V\left(C_{4}^{(3)}\right) & =\left\{x_{1}, x_{2}, x_{3}, x_{4}\right\} .
\end{aligned}
$$

Definisikan pewarnaan titik di $H$ yakni $c: V(H) \longrightarrow\{1,2,3,4\}$ sedemikian sehingga

$$
\begin{aligned}
& c\left(v_{1}\right)=c\left(w_{1}\right)=c\left(x_{1}\right)=1, \\
& c\left(v_{2}\right)=c\left(w_{2}\right)=c\left(x_{3}\right)=2, \\
& c\left(v_{4}\right)=c\left(w_{3}\right)=c\left(x_{2}\right)=3, \\
& c\left(v_{3}\right)=c\left(w_{4}\right)=c\left(x_{4}\right)=4 .
\end{aligned}
$$

Pada pewarnaan titik di atas terlihat bahwa setiap titik bertetangga diwarnai dengan warna yang berbeda. Selanjutnya, akan dilihat kode warna setiap titik di $H$ terhadap $\Pi$ juga berbeda. Misalkan kelas warna sebagai berikut: $\Pi=$ $\left\{S_{1}, S_{2}, S_{3}, S_{4}\right\}$ dengan

$$
\begin{aligned}
& S_{1}=\left\{v_{1}, w_{1}, x_{1}\right\}, \\
& S_{2}=\left\{v_{2}, w_{2}, x_{3}\right\}, \\
& S_{3}=\left\{v_{4}, w_{3}, x_{2}\right\}, \\
& S_{4}=\left\{v_{3}, w_{4}, x_{4}\right\} .
\end{aligned}
$$

Dari definisi pewarnaan titik di atas terlihat bahwa setiap titik bertetangga diwarnai dengan warna yang berbeda.

Kode warna pada setiap titik di $H$ terhadap $\Pi$ sebagai berikut: 


$$
\begin{aligned}
& c_{\Pi}\left(v_{1}\right)=(0,1,1,2), \quad c_{\Pi}\left(v_{2}\right)=(1,0,2,1), \\
& c_{\Pi}\left(v_{3}\right)=(2,1,1,0), \quad c_{\Pi}\left(v_{4}\right)=(1,2,0,1), \\
& c_{\Pi}\left(w_{1}\right)=(0,1,2,1), \quad c_{\Pi}\left(w_{2}\right)=(1,0,1,2), \\
& c_{\Pi}\left(w_{3}\right)=(2,1,0,1), \quad c_{\Pi}\left(w_{4}\right)=(1,2,1,0), \\
& c_{\Pi}\left(x_{1}\right)=(0,2,1,1), \quad c_{\Pi}\left(x_{2}\right)=(1,1,0,2) \text {, } \\
& c_{\Pi}\left(x_{3}\right)=(2,0,1,1), \quad c_{\Pi}\left(x_{4}\right)=(1,1,2,0) .
\end{aligned}
$$

Karena semua titik di graf $H$ memiliki kode warna yang berbeda, maka diperoleh $\chi_{L}^{\prime}(H) \leq 4$ untuk $k=2$,3. Selanjutnya, akan ditunjukkan $\chi_{L}^{\prime}(H) \geq 4$. Jika $\chi_{L}^{\prime}(H)=3$ maka akan terdapat dua titik yang memiliki kode warna yang sama, yaitu titik- titik yang memiliki kelas warna yang sama pada suatu graf tersebut. Jadi, diperoleh bahwa $\chi_{L}^{\prime}(H) \geq 4$ untuk $k=2,3$. Dari pembuktian $\chi_{L}^{\prime}(H) \leq 4$ dan $\chi_{L}^{\prime}(H) \geq 4$ untuk $\mathrm{k}=2,3$ dapat disimpulkan bahwa $\chi_{L}^{\prime}(H)=4$ untuk $k=2,3$.

Kasus 2. Akan ditunjukkan $\chi_{L}^{\prime}(H)=\infty$ untuk $k$ lainnya. Andaikan $\chi_{L}^{\prime}(H)=4$ artinya $H$ mempunyai pewarnaan 4-lokasi. Jika $H$ mempunyai pewarnaan 4-lokasi dengan $k \geq 4$ maka akan terdapat dua titik yang mempunyai kode warna yang sama. Andaikan $\chi_{L}^{\prime}(H)=5$ artinya $H$ mempunyai pewarnaan 5-lokasi. Jika $H$ mempunyai pewarnaan 5-lokasi maka terdapat titik $v$ di $H$ yang mempunyai $c_{\Pi}(v)=\left(d\left(v, S_{5}\right)\right)=\infty$. Akibatnya $\chi_{L}^{\prime}(H)=\infty$.

\section{Kesimpulan}

Misalkan $C_{4}$ adalah sebuah lingkaran dengan 4 titik. jika $H=k C_{4}$, Maka

$$
\chi_{L}^{\prime}(H)=\left\{\begin{array}{l}
4, \text { untuk } k=2,3 \\
\infty, \text { untuk lainnya }
\end{array}\right.
$$

\section{Ucapan Terima kasih}

Terima kasih kepada Ibu Dr. Lyra Yulianti, Bapak Yudiantri Asdi. M.Sc dan Bapak Dr. Jenizon selaku penguji sehingga penelitian ini dapat terlaksana dengan baik.

\section{Daftar Pustaka}

[1] Chartrand, G., Erwin, D., Henning, M.A., Slater, P.J. dan Zhang, P. 2002. The Locating Chromatic Number of a Graph. Bull Inst. Combin. Appl. 36: $89-101$

[2] Chartrand, G., Erwin, D., Henning, M.A., Slater, P.J. dan Zhang, P. 2003. Graph of Order $n$ With Locating-Chromatic Number n-1. Discrete Math. 269: $65-79$

[3] Welyyanti, D., Baskoro, E.T, Simanjuntak, R., Utunggadewa, S. 2014. The locating-Chromatic Number of Disconnected Graph. Far East Journal of Mathematical Science. 94(2): 169 - 182 